\title{
GC-MS and Preliminary Phytochemical Constituents of Costus Afer Crude Stem Juice
}

\author{
Egege AN, Nwaogwugwu JC*, Nosiri CI and Okereke SC \\ Department of Biochemistry, Abia State University, Nigeria
}

*Corresponding author: Nwaogwugwu JC, Department of Biochemistry, Faculty of Biological Sciences, Abia State University, Uturu, Nigeria, Tel: 08060539271; Email: ifesinachinwa@gmail.com

\section{Research Article \\ Volume 3 Issue 4}

Received Date: November 21, 2019

Published Date: December 03, 2019

DOI: $10.23880 /$ macij- 16000149

\section{Abstract}

The present study investigated phytochemical constituents of Costus afer crude stem juice. The preliminary phytochemical screening revealed the presence of alkaloid, flavonoid, phenol, tannin, anthraquinones, cardiac glycosides and terpenoids while the juice showed absence of saponin, phlobatannin, cardenolide, cyanogenic glycosides and oxalates. Thirty compounds were identified in the GC/MS analysis of Costus afer stem juice. The individual names of compounds identified with respect to their individual peak number, retention time, area \%, molecular weight are shown. Among the compound identified are; 2 Furancaboxaldehyde, 5-(hydroxymethyl) was present with percentage peak area of $70.357 \%$ and retention time of 5.417 forming the major constituents in the juice followed by B-D-Glucopyranoside, methyl 3,6-anhydro with the percentage area of 5.390\% and retention time of 8.869. Hexadecanoic acid, ethyl ester was also detected with percentage area of $4.320 \%$ and retention time of 10.27 . Maltol was detected with percentage peak of $3.428 \%$ and retention time of 5.649. Dl-Malic disodiumsalt was detected with percentage peak of 3.041\%. Other compounds present were Silicic acid, diethyl bis (trimethylsilyl) ester with percentage peak area of $0.354 \%$ and retention time of 15.01 . N-Hexadecanoic acid with percentage peak area of $0.293 \%$ and retention time of 9.848. Furazan-3-ol, 4amino with percentage peak area of $0.288 \%$ and retention time of 6.466 . Deferent compounds has been reported to possess different biological activities like; antioxidant, flavouring agent, and anti-inflammatory properties, anti-apoptotic effects, Anticonvulsant, antifatique, antitumor activity and cancer-preventive effect. The properties accounts for the use of this plant for medicinal purposes.

Keywords: GCMS; Phytochemical; Costus afar; Terpenoids; Alkaloid

\section{Introduction}

Nature has been a source of medicinal agents since times immemorial. The importance of medicinal plants in the management of human ailments cannot be over emphasized. It is clear that the plant kingdom harbours an inexhaustible source of active ingredients invaluable in the management of many intractable diseases $[1,2]$. The term medicinal plants include various types of plants used in herbalism due their medicinal activities. These medicinal plants are considered as rich sources of ingredients which can be used in drug development 


\section{Medicinal \& Analytical Chemistry International Journal}

synthesis. They have provided mankind with herbal remedies for many diseases for many centuries till date because they are good sources of bioactive compounds [3]. Phytochemical are bioactive chemicals of plant origin. They are regarded as secondary metabolites because the plants that manufacture them may have little need for them. Phytochemicals have been recognized as the basis for the traditional herbal medicine. Costus afer which belongs to the family Zingiberaceae is a monocot and a relatively tall, herbaceous, unbranched tropical plant with creeping rhizome. It is commonly found in moist or shady forest of West and Tropical Africa [4]. It has been reported that Costus afer possesses medicinal properties such as anti-diabetic, anti-inflammatory, anti-anthritic and treatment of various diseases such as cough, measles and different skin ailment. In view of all these reported medicinal effectiveness of the stem of this plant, the aim of this present study is to evaluate the bioactive constituents of this plant stem juice so as to ensure holistic use of the plant in treatment and management of diseases.

\section{Materials and Methods}

The whole plant of Costus afer was harvested at Amuke, Isiala Ngwa south L.G.A. in Abia state. The plant was identified at the Department of Plant Science and Biotechnology, Abia State University, Uturu and voucher specimen deposited at the herbarium of the Department. The leaves were removed from the stem and then were debarked. The debarked stems were introduced into a clean manual blender and were crushed to squeeze out their juice. The resulting juice was filtered using a sterile Muslin cloth and Whatman No 1 filter paper. The juice was concentrated by lyophilizing in a freeze dryer (Edwards, USA). The dried juice was stored in air tight amber bottle.

\section{Preliminary Phytochemical Screening}

The methods described by Trease and Evans (1989) [5], alkaloid, flavonoid, phenol, Saponin, Phlobatannin and Cardenolide while Harborne (1973) [6,7] and Sofowora (1993) [8] method was used to test for Cardiac Glycosides and terpenoid, tannin, Anthraquinones, and Oxalates.

\section{Phytochemicals Analysis of Costus afer Stems Juice using GC-MS}

The samples for GC-MS were prepared by dissolving $3 \mathrm{~g}$ of extracted powder in methanol solvent. For the analysis, GC-MS-QP 2010 SHIMADZU instrument was used. To analyze the sample the column oven temperature and Injector temperature was set at $800^{\circ} \mathrm{C}$ and $200^{\circ} \mathrm{C}$ respectively. The flow control mode was maintained in linear velocity with a split injection mode split ratio of 20 . The column flow was $1.46 \mathrm{ml} / \mathrm{min}$ with a helium carrier gas of $99.9995 \%$ purity. The column oven temperature program was set as follows:

The temperature was set at $80^{\circ} \mathrm{C}$ with 2 mins hold time by the rate of 10 . The temperature was $300^{\circ} \mathrm{C}$ with 10 minutes hold time. The column at 5 mins was used with a length of 30 millimeters and diameter of $0.25 \mathrm{~mm}$ and its film thickness will be $0.25 \mu \mathrm{m}$. The ion source temperature for MS condition was $200^{\circ} \mathrm{C}$ and interface temperature was $240^{\circ} \mathrm{C}$. Starting $\mathrm{m} / \mathrm{z}$ (Mass to charge) ratio was 40 and ending with $\mathrm{m} / \mathrm{z}$ ratio of 700 (40$700 \mathrm{~m} / \mathrm{z}$ ).

\section{Identification of the Phytochemical Constituents}

Identification and interpretation of mass spectrum of GC-MS was conducted using the National Institute of Standard and Technology (NIST) database. The unknown components were compared with spectrum of known components stored in the NIST library. The name, molecular weight and structures of the components of the test materials were ascertained (Table 1 ).

\begin{tabular}{|c|c|}
\hline Phytochemical & Presence \\
\hline Alkaloids & ++ \\
\hline flavonoids & ++ \\
\hline Saponins & - \\
\hline Phenols & ++ \\
\hline Tannins & + \\
\hline Anthraquinones & + \\
\hline Cardiac Glycosides & + \\
\hline Phlobatannins & ++ \\
\hline Terpenoids & - \\
\hline Cardenolides & - \\
\hline Cyanogenic Glycosides & - \\
\hline Oxalates & \\
\hline
\end{tabular}

Key: $+=$ present, $++=$ Abundant, $-=$ absent

Table 1: The Phytochemical Constituents of Aqueous Costus afer Stem juice.

The preliminary phytochemical results above show the presence of Alkaloid, Flavonoid, phenol, Tannin, Anthraquinones, Cardiac Glycosides and Terpenoids. The extract showed absence of Saponin, Phlobatannin, Cardenolides, Cyanogenic Glycosides and Oxalates. 


\section{Medicinal \& Analytical Chemistry International Journal}

Result of the GC-MS analysis of Costus afer stem juice shows 30 compounds were present in the plant juice analysed. Furancaboxaldehyde, 5-(hydroxymethyl)- was present with percentage peak area of $70.357 \%$ and retention time of 5.417 forming the major constituents in the juice followed by B-D-Glucopyranoside, methyl 3,6anhydro- with the percentage area of $5.390 \%$ and retention time of 8.869. Hexadecanoic acid, ethyl ester was also detected with percentage area of $4.320 \%$ and retention time of 10.27. Maltol was detected with percentage peak of $3.428 \%$ and retention time of 5.649 . Dl-Malic disodiumsalt was detected with percentage peak of $3.041 \%$. Malic acid was detected with percentage peak of $2.288 \%$ and retention time of 5.904. 9,12Octadecadienoyl chloride, (Z,Z) was detected with percentage peak of $1.872 \%$ and retention time of 15.53 . Cyclopentaneundecanoic acid, methyl ester was detected with percentage peak area of $1.553 \%$ and retention time of 18.09. Ethyl $\beta$-d-riboside was detected with percentage peak area of $1.433 \%$ and retention time of $8.266 .1,6 ; 3,4$ Dianhydro-2-0-acetyl- $\beta$-d-galactopyranose was detected with percentage peak area of $0.788 \%$ and retention time of 6.024. 2-Naphthalenol, decahydro, $(2 \alpha, 4 \mathrm{a} \alpha, 8 \mathrm{a} \beta)$ was detected with percentage peak area of $0.616 \%$ and retention time of 11.32. Conhydrin was detected with percentage peak area of $0.515 \%$ and retention time of 6.616. Butanedioic acid, hydroxyl-diethyl ester, $( \pm)$ was detected with percentage peak area of $0.399 \%$ and retention time of 6.002. I-Gala-I-ido-octose was detected with percentage peak area of $0.399 \%$ and retention time of 18.19. Pterin-6-carboxylic acid was detected with percentage peak area of $0.375 \%$ and retention time of 27.12. Other compounds present were Silicic acid, diethyl bis (trimethylsilyl) ester with percentage peak area of $0.354 \%$ and retention time of 15.01 .

$\mathrm{N}$-Hexadecanoic acid with percentage peak area of $0.293 \%$ and retention time of 9.848. Furazan-3-ol 4amino with percentage peak area of $0.288 \%$ and retention time of 6.466. 1-Heptatriacotanol with percentage peak area of $0.256 \%$ and retention time of 34.35 . 6-epishyobunol with percentage peak area of $0.258 \%$ and retention time of 27.1. Urea, ethyl with percentage peak area of $0.222 \%$ and retention time of 11.51 . Cyclohexane, 1-butyl- was detected with percentage peak area of $0.220 \%$ and retention time 10.61 . Farnesyl bromide was detected with percentage area of $0.190 \%$ and retention time of 18.54. Linoleic acid ethyl ester was detected with percentage area of $0.185 \%$ and retention time of 10.76 . Squalene was detected with percentage peak area of $0.184 \%$ and retention time of 31.95. 3-Hydroxy-4methoxybenzoic acid Squalene was detected with percentage peak area of $0.178 \%$ and retention time of 7.711. 3,7,11,15-Tetramethyl-2-hexadecen-1-ol was detected with percentage peak area of $0.173 \%$ and retention time of 17.58. D-Allose was detected with percentage peak area of $0.163 \%$ and retention time of 7.381. 1,6-Anhydro-B-D-glucofuranose was detected with percentage peak area of $0.153 \%$ and retention time of 7.827. Dihydro-3-methylene-5-methyl-2-furanone was detected with percentage peak area of $0.149 \%$ and retention time of 6.369 (Figure 1).

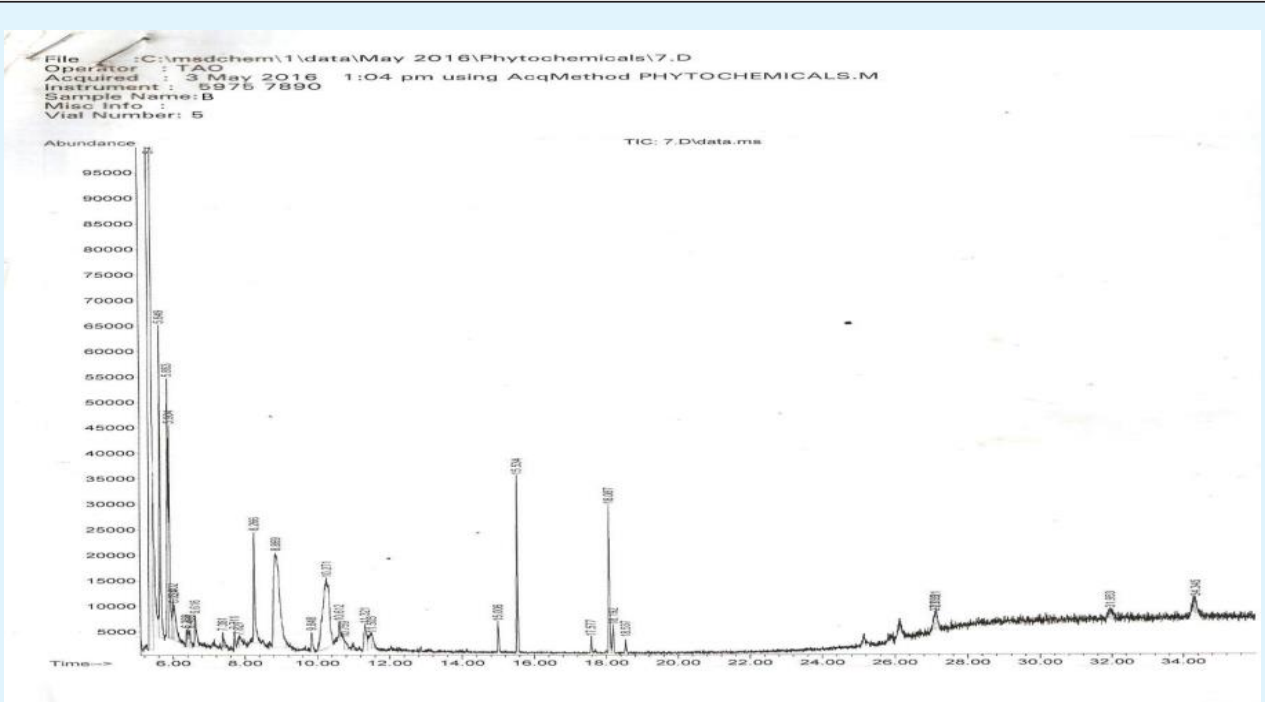

Figure 1: Chromatogram of GC-MS analysis of Costus afer crude stem juice: shows the retention time, $\%$ area and various peaks of the bioactive compounds. 


\section{Medicinal \& Analytical Chemistry International Journal}

\section{Discussion}

Phytochemicals have been recognized as the basis for the tradition herbal medicine. The presence of various types of phytochemicals in plants has been implicated in the health promoting properties of medicinal plants. Sequel to this knowledge, the importance of determining the phytoconstituents and biological active substances considered for nutritional and medicinal purposes arose and hence the present study aimed at assessing the phytochemicals present in Costus afer. The preliminary phytochemical analysis of Costus afer stem juice revealed the presence alkaloid, flavonoid, phenol, tannin, anthraquinones, cardiac glycosides and terpenoid and the absence of saponin, phlobatannin, cardenolide, cyanogenic glycosides and oxalates. Alkaloids are known to have anti-microbial, antifungal and anti-inflammatory effect and it also acts as an anti-hypertensive agent $[9,10]$. The use of Costus afer in Ethnomedcine as an antihypertensive agent may be attributed to the presence of alkaloid [11]. The folkloric use of C. afer in the treatment of sore throat, diarrhea, hemorrhage and wound healing might be due to presence of tannins. Cardiac glycosides had been reported to be effective in the treatment of congestive heart failure and regulation of heart beat. Anthraquinones can induce laxative effect and hence, the use of $C$. afer as laxative and nervous system depressant may result from the presence of anthraquinones [12] Flavonoids and phenols were abundant in the extract. These are potent water soluble antioxidants which prevent oxidative cell damage suggesting antiseptics, anticancer, anti-inflammatory effects and mild antihypertensive properties. Furthermore, plant phenolics are major group of compounds acting as primary antioxidants or free radical scavengers. The therapeutic potential of antioxidants in controlling degenerative diseases with marked oxidative damage from reactive oxygen species or free radicals have been reported [13]. High phenolic content showed high antioxidant and inhibition of lipid peroxidative activity. These suggest its potential in the treatment and prevention of various oxidative related diseases. These phytochemical constituents of stem extract of Costus afer provide some biochemical basis for its ethno pharmacological uses in the treatment and prevention of various diseases and disorders.

The Costus afer crude stem juice contains rich phytochemical constituents. Thirty compounds were identified in the GC/MS analysis. The individual names of compounds identified with respect to their individual peak number, retention time, area \%, molecular weight were shown in Table 2. Among the compound identified are; 2 Furancaboxaldehyde, 5-(hydroxymethyl)- was present in $70.357 \%$ forming one of the major constituents in the juice followed by B-D-Glucopyranoside, methyl 3,6anhydro- (5.390\%), Hexadecanoic acid, ethyl ester(4.320\%), Maltol (3.428\%), dl-Malic disodiumsalt (3.041\%), Malic acid (2.288\%), 9,12-Octadecadienoyl chloride, (Z,Z)- (1.872\%), Cyclopentaneundecanoic acid, methyl ester (1.553\%), Ethyl $\beta$-driboside(1.433\%),1,6;3,4-Dianhydro-2-0-acetyl- $\beta$-dgalactopyranose $(0.788 \%), 2$-Naphthalenol, decahydro-, $(2 \alpha, 4 \mathrm{a} \alpha, 8 \mathrm{a} \beta)-\quad(0.616 \%), \quad$ Conhydrin $\quad(0.515 \%)$, Butanedioic acid, hydroxyl-, diethyl ester, ( \pm ) (0.399\%), IGala-I-ido-octose (0.399\%), Pterin-6-carboxylic acid $(0.375 \%)$. Other compounds present were Silicic acid, diethyl bis (trimethylsilyl) ester (0.354\%), nHexadecanoic acid (0.293\%), Furazan-3-ol, 4-amino(0.288\%), 1-Heptatriacotanol (0.256\%), 6-epi-shyobunol (0.258\%), Urea, ethyl- 0.222\%), Cyclohexane, 1-butyl$(0.220 \%)$, Farnesyl bromide $(0.190 \%)$, Linoleic acid ethyl ester $(0.185 \%)$, Squalene $(0.184 \%), \quad 3$-Hydroxy-4methoxybenzoic acid $(0.178 \%), 3,7,11,15$-Tetramethyl-2hexadecen-1-ol (0.173\%), D-Allose (0.163\%), 1,6Anhydro-B-D-glucofuranose $\quad(0.153 \%), \quad$ Dihydro-3methylene-5-methyl-2-furanone $(0.149 \%)$. All these compounds constitute $100.00 \%$ of the plant.

\begin{tabular}{|c|c|c|c|c|c|}
\hline S.No & RT & Compound Name & Formula & MW & Area, $\%$ \\
\hline 1 & 5.417 & 2-Furancaboxaldehyde, 5-(hydroxymethyl)- & $\mathrm{C}_{6} \mathrm{H}_{6} \mathrm{O}_{3}$ & 126 & 70.357 \\
\hline 2 & 5.649 & Maltol & $\mathrm{C}_{6} \mathrm{H}_{6} \mathrm{O}_{3}$ & 126 & 3.428 \\
\hline 3 & 5.863 & $\mathrm{C}_{4} \mathrm{H}_{6} \mathrm{O}_{5}$ & 134 & 3.041 \\
\hline 4 & 5.904 & dl-Malic disodiumsalt & $\mathrm{C}_{4} \mathrm{H}_{6} \mathrm{O}_{5}$ & 134 & 2.288 \\
\hline 5 & 6.002 & Malic acid & $\mathrm{C}_{8} \mathrm{H}_{14} \mathrm{O}_{5}$ & 190 & 0.399 \\
\hline 6 & 6.024 & 1,6;3,4-Dianhydro-2-O-acetyl-, diethyl ester, $( \pm)-$ & $\mathrm{C}_{8} \mathrm{H}_{10} \mathrm{O}_{5}$ & 186 & 0.788 \\
\hline 7 & 6.369 & Dihydro-3-methylene-5-methyl-2-furanone & $\mathrm{C}_{6} \mathrm{H}_{8} \mathrm{O}_{2}$ & 112 & 0.149 \\
\hline 8 & 6.466 & Furazan-3-ol, 4-amino- & $\mathrm{C}_{2} \mathrm{H}_{3} \mathrm{~N}_{3} \mathrm{O}^{2}$ & 101 & 0.228 \\
\hline 9 & 6.616 & Conhydrin & $\mathrm{C}_{8} \mathrm{H}_{17} \mathrm{NO}_{\mathrm{O}}$ & 143 & 0.515 \\
\hline 10 & 7.381 & $\mathrm{C}_{6} \mathrm{H}_{12} \mathrm{O}_{6}$ & 180 & 0.163 \\
\hline 11 & 7.711 & $\mathrm{C}_{8} \mathrm{H}_{8} \mathrm{O}_{4}$ & 168 & 0.178 \\
\hline
\end{tabular}




\section{Medicinal \& Analytical Chemistry International Journal}

\begin{tabular}{|c|c|c|c|c|c|}
\hline 12 & 7.827 & 1,6-Anhydro- $\beta$-D-glucofuranose & $\mathrm{C}_{6} \mathrm{H}_{10} \mathrm{O}_{5}$ & 162 & 0.153 \\
\hline 13 & 8.266 & Ethyl $\beta$-d-riboside & $\mathrm{C}_{7} \mathrm{H}_{14} \mathrm{O}_{5}$ & 178 & 1.433 \\
\hline 14 & 8.869 & B-D-Glucopyranoside, methyl 3,6-anhydro- & $\mathrm{C}_{7} \mathrm{H}_{12} \mathrm{O}_{5}$ & 176 & 5.39 \\
\hline 15 & 9.848 & n-Hexadecanoic acid & $\mathrm{C}_{16} \mathrm{H}_{32} \mathrm{O}_{2}$ & 256 & 0.293 \\
\hline 16 & 10.27 & Hexadecanoic acid, ethyl ester & $\mathrm{C}_{18} \mathrm{H}_{36} \mathrm{O}_{2}$ & 284 & 4.32 \\
\hline 17 & 10.61 & Cyclohexane, 1-butyl- & $\mathrm{C}_{10} \mathrm{H}_{18}$ & 138 & 0.22 \\
\hline 18 & 10.76 & Linoleic acid ethyl ester & $\mathrm{C}_{20} \mathrm{H}_{36} \mathrm{O}_{2}$ & 308 & 0.185 \\
\hline 19 & 11.32 & $\mathrm{C}_{10} \mathrm{H}_{18} \mathrm{O}$ & 154 & 0.616 \\
\hline 20 & 11.51 & 2-Naphthalenol, decahydro-, $(2 \alpha, 4 a \alpha, 8 a \beta)-$ & $\mathrm{C}_{3} \mathrm{H}_{8} \mathrm{~N}_{2} \mathrm{O}$ & 88 & 0.222 \\
\hline 21 & 15.01 & Urea, ethyl- & $\mathrm{C}_{10} \mathrm{H}_{28} \mathrm{O}_{4} \mathrm{Si}_{3}$ & 296 & 0.354 \\
\hline 22 & 15.53 & Silicic acid, diethyl bis(trimethylsilyl) ester & $\mathrm{C}_{18} \mathrm{H}_{31} \mathrm{Cll}_{\mathrm{O}}$ & 298 & 1.872 \\
\hline 23 & 17.58 & 9,12-Octadecadienoyl chloride, $(Z, Z)-$ & $\mathrm{C}_{20} \mathrm{H}_{40} \mathrm{O}$ & 296 & 0.173 \\
\hline 24 & 18.09 & Cyclopentaneundecanoic acid, methyl ester & $\mathrm{C}_{17} \mathrm{H}_{32} \mathrm{O}_{2}$ & 268 & 1.553 \\
\hline 25 & 18.19 & I-Gala-I-ido-octose & $\mathrm{C}_{8} \mathrm{H}_{16} \mathrm{O}_{8}$ & 240 & 0.399 \\
\hline 26 & 18.54 & Farnesyl bromide & $\mathrm{C}_{15} \mathrm{H}_{25} \mathrm{Br}_{2}$ & 284 & 0.19 \\
\hline 27 & 27.1 & 6-epi-shyobunol & $\mathrm{C}_{15} \mathrm{H}_{26} \mathrm{O}$ & 222 & 0.258 \\
\hline 28 & 27.12 & $\mathrm{C}_{7} \mathrm{H}_{5} \mathrm{~N}_{5} \mathrm{O}_{3}$ & 207 & 0.375 \\
\hline 29 & 31.95 & Pterin-6-carboxylic acid & $\mathrm{C}_{30} \mathrm{H}_{50}$ & 410 & 0.184 \\
\hline 30 & 34.35 & Squalene & $\mathrm{C}_{37} \mathrm{H}_{76} \mathrm{O}$ & 536 & 0.276 \\
\hline
\end{tabular}

key: RT: Retention Time; MW: Molecular weight

Table 2: GC-MS Phytochemical analysis of Costus afer stems juice.

It has been reported that 2-Furancaboxaldehyde, 5 (hydroxymethyl) has favorable biological effects such as anti-oxidant activity, and inhibition of sickling of red blood cells [14-16]. This is because the mechanism of hypoxic injury contains the process of oxidative stress and 5-HMF can protect hepatocyte cell lines against damage induced by $\mathrm{H}_{2} \mathrm{O}_{2}$ in vitro [17-19]. It also portrays antimicrobial and preservative effect [20].

Maltol (2-methyl-3-hydroxy-1,4-pyrone) is a naturally occurring substance that is widely used as a flavoring agent. It is formed through thermal degradation of starch or sucrose pyrolysis, but is also used in medications such as vanadyl maltolate for the treatment of diabetes, and ferric trimaltol for the treatment of iron deficiency anemia, it has been reported that maltol has a neuroprotective effect through its antioxidant properties, and anti-apoptotic effects. Maltol has Anticonvulsant, antifatique, antitumour activity and cancer-preventive effect.

Conhydrin is efficient in anti-salmonella and anticoronary activities [21]. Butanedioic acid, hydroxyl-, diethyl ester, $( \pm)$ - has been reported to be anti-ulceric in nature [22]. 1,6-Anhydro- $\beta$-D-glucofuranose possesses biological activities such as the anti-human immunodeficiency virus and blood anticoagulant activities [23]. Sermakkani and Thangapandian [24] reported n-Hexadecanoic acid to be implicated in biological activities such as Antioxidant, Hypocholesterolemic Nematicide, Pesticide, Lubricant, Antiandrogenic, Flavor, Hemolytic.

Hexadecanoic acid, ethyl ester has Antioxidant, Flavor, Hypocholesterolemic Nematicide, Pesticide, Lubricant, Antiandrogenic, Hemolytic, 5- Alpha reductase inhibitor activities. 3,7,11,15-Tetramethyl-2-hexadecen-1-ol has been reported to have activities such asantimicrobial, antioxidant, Antituberculosis , insecticidal, antiinflammatory, antioxidant, antimicrobial, Anticancer, Diuretic. 9,12-Octadecadienoyl chloride, (Z,Z)- has been reported to possess antisecretory antispermigenic, antitonsilitic, antitubercular, choleretic, contraceptive activities [25].

Parthipan, et al. (2014) [26] reported that Cyclopentaneundecanoic acid, methyl ester has antimicrobial activity. L-gala-l-ido-octose is used for the synthesis of higher sugar necessary for the production of drugs used to specifically facilitate learning or memory, particularly to prevent the cognitive deficits associated with dementias [27]. 6-epi-shyobunol was reported to show Pharmacological effect, such as anti-inflammatory, antioxidant activities [28].

Pterin-6-carboxylic acid has been reported to possess anti-psychotic, mood stabilizer and anti-parasitic activities. Squalene has been reported to possess 


\section{Medicinal \& Analytical Chemistry International Journal}

Antibacterial, Antioxidant, Pesticide, Antitumor, Cancer preventive, Immunostimulant, Chemo-preventive and Lipoxygenase- inhibitor activities [29,30]. Heptatriacontanol, a C37 aliphatic alcohol may exhibit such activity. It also portrays anti-cancer, anti-neoplastic and anti-HIV.

\section{References}

1. Ekta M, Ojha CK, Negi RS, Yukta A, Arvind P (2011) Screening of Indian Medicinal Plants and their potentials as Antimicrobial. Global Journal of Science Frontier Research 11(2): 1-7.

2. Fonge BA, Egbe EA, Fongod AGN, Focho DA, Tchetcha DJ, et al. (2012) Ethnobotany Survey and uses of Plants in the Lewoh- Lebang Communities in the Lebialem Highlands, South West Region, Cameroon. Journal of Medicinal Plants Research 6(5): 855-865.

3. Bassam ARH (2012) Medicinal Plants (Importance and Uses). Pharmaceutica Analytica Acta 3(10).

4. Ukpabi CF, Agbafor KN, Ndukwe OK, Agwu A, Nwachukwu A (2012) Phytochemical Composition of Costus afer extract and its alleviation of carbon tetrachloride-induced hepatic oxidative stress and toxicity. International Journal of Modern Botany 2(5): 120-126.

5. Trease GE, Evans WC (1989) Pharmacognosy. 11 th (Edn.), Macmillan Publishers, London, UK.

6. Harborne JB (1973) Phytochemical methods: A guide to modern techniques of plant analysis. Chapman and Hall Ltd, London, pp: 279.

7. Harborne JB (1973) Phytochemical Methods. Chapman and Hall Ltd, London, UK, pp: 49-188.

8. Sofowora A (1982) Medicinal plants and traditional Medicine in Africa. Spectrum Books Limited, Ibadan, Nigeria, 6: 154.

9. Okwu DE (2004) Phytochemicals and Vitamin Content of Indigenous Spices of South Eastern Nigeria. Journal of Sustain Agricultural Environment 6(2): 30-34.

10. Okwu DE (2004) Phytochemicals and Vitamin content of indigenous species of southeastern Nigerian. J Sustain Agric Environ 6(1): 30-37.
11. Omokhua GE (2011) Medicinal and Socio-Cultural Importance of Costus afer (Ker Grawl). International Multidisciplinary Journal 5(5): 282-287.

12. Muller-Lissner SA (1993) Adverse Effects of laxatives Fact and Fiction. Pharmacology 47(1): 138-145.

13. Larson Richard A (1988) The antioxidants of higher plants. Phytochemistry 27(4): 969-978.

14. Zhao K, Ao Y, Harper RM, Go VL, Yang H (2013) Foodintake dysregulation in type 2 diabetes. Neroscience 247: 43-54.

15. Li MM, Wu LY, Zhao T, Xiong L, Huang X, et al. (2011) The protective role of 5-hmf against hypoxic injury. Cell Stress Chaperones 16(3): 267-273.

16. Janzowski C, Glaab V, Samimi E, Schlatter J, Eisenbrand G (2000) 5-hydroxymethylfurfural: Assessment of mutagenicity, DNA-damaging potential and reactivity towards cellular glutathione. Food Chem Toxicol 38(9): 801-809.

17. Powell RD, Swet JH, Kennedy KL, Huynh TT, McKillop IH, et al. (2014) Resveratrol attenuates hypoxic injury in a primary hepatocyte model of hemorrhagic shock and resuscitation. J Trauma Acute Care Surg 76(2): 409-417.

18. Ding X, Wang MY, Yao YX, Li GY, Cai BC (2010) Protective effect of 5-hydroxymethylfurfural derived from processed Fructus corni on human hepatocyte injured by hydrogen peroxide and its mechanism. J Ethnopharmacol 128(2): 373-376.

19. Wei-Li, Xin-Nan Q, Ye H, Si-Wen Z, Jia W, et al. (2015) Ameliorative Effects of 5-Hydroxymethyl-2-furfural (5-HMF) from Schisandra chinensis on Alcoholic Liver Oxidative Injury in Mice. Int J Mol Sci 16(2): 2446-2457.

20. Varsha J, Vaibhav K, Poonam P (2014) GC-MS analysis of bioactive compounds in methanolic extract of Holigarna grahamii (wight) Kurz. International Journal of Herbal Medicine 2(4):35-39.

21. Chandel E, Bhupender K (2015) Antimicrobial Activity and Phytochemical Analysis of Cynodon dactylon: A Review. World Journal of Pharmacy and Pharmaceutical Sciences 4(11): 515-530.

22. Al-Marzoqi AH, Hameed IH, Idan SA (2015) Analysis of bioactive chemical components of two medicinal 


\section{Medicinal \& Analytical Chemistry International Journal}

plants (Coriandrum sativum and Melia azedarach) leaves using gas chromatography-mass spectrometry (GC-MS). Journal of Biotechnology 14(40): 281-2830.

23. Takahashi K, Satoh H, Satoh T, Kakuchi T, Miura M, et al. (2009) Formation kinetics of levoglucosan from glucose in high temperature water. Chemical Engineering Journal 153(1-3):170-174.

24. Sermakkani M, Thangapandian V (2012) Gc-Ms Analysis of Cassia Italica Leaf Methanol Extract. Asian Journal of Pharmaceutical and Clinical Research 5(2): 90-94.

25. Kalaivani CS, Sathish SS, Janakiraman N, Johnson M (2012) GC-MS studies on Andrographis paniculata (Burm.f.) Wall. ex Nees-A medicinally important plant. Int J Med Arom Plants 2(1): 69-74.

26. Parthipan B, Mohan Das N, Sundari SS, Karuppusamy S, Mohan VR (2014) GC-MS Analysis of Leaf and Stem Bark of Cleidion nitidum (Muell.-Arg.) Thw. Ex Kurz. (Euphorbiaceae). Asian Journal of Pharmaceutical and clinical Research 7(2): 41-47.
27. Moussaid M, Adly F, Berhal C, Razik A, Elamrani AA, et al. (2015) Study on Chemical Components of Ethanol Extractives of Dipcadi serotinum (Hyacinthaceae) By GC/MS. International Journal of Current Research and Academic Review 3(9): 134-139.

28. Hameed IH, Altameme HJ, Idan AS (2016) Artemisia annua: Biochemical products analysis of methanolic aerial parts extract and anti-microbial capacity. Research Journal of Pharmaceutical, Biological and Chemical Sciences 7(2): 1843-1868.

29. Lafleur-brooks M (2008) Exploring Medical language: A student-directed Approach, $7^{\text {th }}$ (Edn.), St. Louis, Mosby Elsevier, Missouri, U.S.A, pp: 398.

30. Powers D, Hit A (1993) Sickle cell anaemia, beta S. gene clusther haplotypes as genetic markers for severe disease expression. Am J Dis Child 147(11): 1197-1202. 